International Business and Global Economy 2018, no. 37, pp. 363-373

Biznes międzynarodowy w gospodarce globalnej 2018, nr 37, s. 363-373

Edited by the Institute of International Business, University of Gdańsk

\title{
Znaczenie inteligencji kulturowej w międzynarodowych badaniach marketingowych
}

Rozszerzanie działalności przedsiębiorstw poza rynek krajowy wiąże się ze wzrostem ryzyka i niepewności podejmowanych działań, stąd potrzeba profesjonalnego zbierania i przetwarzania informacji o nowych rynkach. Interesującą perspektywę do tego, jak można patrzeć na prowadzenie międzynarodowych badań marketingowych, wnosi koncepcja inteligencji kulturowej (CQ). Niniejszy artykuł jest próbą odpowiedzi na pytanie o to, jakie znaczenie mają poszczególne komponenty inteligencji kulturowej na różnych etapach procesu badań marketingowych prowadzonych w międzynarodowym kontekście. Przedstawiono koncepcję CQ jako strukturę kilku współzależnych, wzajemnie na siebie oddziałujących komponentów oraz sformułowano przypuszczenia dotyczące znaczenia wykorzystania komponentów $C Q$ w procesie badań międzynarodowych.

Słowa kluczowe: inteligencja kulturowa, międzynarodowe badania marketingowe

Klasyfikacja JEL: M31, F23

\section{The meaning of cultural intelligence in international marketing research}

The expansion of business activity outside the domestic market is connected to an increasing risk and uncertainty of the undertaken actions, hence the need to collect and process information on the new markets in a professional way. Cultural intelligence provides an interesting perspective into how one can perceive international marketing research. The paper is an attempt to answer the question of what is the meaning of particular components of cultural intelligence regarding different stages of marketing research in the international context. The concept of CQ is presented as a structure of interrelated components and assumptions have been formulated on the significance of applying those components in the process of international marketing research.

Keywords: intercultural intelligence, international marketing research

JEL classification: M31, F23 


\section{Wprowadzenie}

Co umożliwia jednostkom skuteczną interakcję z przedstawicielami innych kultur? Jakie umiejętności są do tego niezbędne? Czy to możliwe, że niektórzy menedżerowie, choć odznaczają się wysoką inteligencją społeczną we własnym środowisku, zupełnie sobie nie radzą w obcym otoczeniu kulturowym? W wyniku poszukiwania odpowiedzi na takie i podobne pytania w kontekście zarządzania międzynarodowego, na początku XXI w. pojawiła się koncepcja inteligencji kulturowej. Osoba inteligentna kulturowo jest świadoma tego, co uchodzi za stosowne zachowanie $w$ różnych kulturach, i potrafi efektywnie współpracować z przedstawicielami tych kultur. Umiejętność ta staje się powoli niezbędna wobec takich wyzwań współczesności, jak globalizacja, internacjonalizacja czy właśnie wielokulturowość. Dotychczas różne komponenty inteligencji kulturowej były analizowane m.in. w kontekście rozwijania kompetencji międzykulturowych poprzez kształcenie [Eisenberg i in., 2013], stylów przywództwa międzykulturowego [Alon, Higgins, 2005], negocjacji międzynarodowych [Groves, Feyerherm, Gu, 2015] czy zarządzania zróżnicowanymi kulturowo zespołami [Simpson, 2015]. Niniejszy artykuł jest próbą odpowiedzi na pytanie, w jaki sposób poszczególne elementy inteligencji kulturowej mogą być wykorzystane w procesie międzynarodowych badań marketingowych.

\section{Inteligencja kulturowa i jej komponenty}

Pojęcie inteligencji kulturowej (CQ) wprowadził Christopher Earley [Earley, 2002; Earley, Ang, 2003], definiując ją jako zdolność jednostki do skutecznego dostosowania się do odmiennych uwarunkowań kulturowych. Jednostki o wysokim CQ posiadają szeroki zakres zdolności poznawczych, behawioralnych oraz motywacyjnych, umożliwiających im efektywną współpracę z członkami innych kultur i adaptację do nowego otoczenia. Koncepcję inteligencji kulturowej rozwijali w dalszych badaniach m.in. David C. Thomas i Kerr Inkson [2004], P. Christopher Earley i Elaine Mosakowski [2004] oraz Elisabeth Plum [2007].

Inteligencja kulturowa jest pewnym konstruktem, czyli abstrakcją pojęciową reprezentującą zjawisko, które nie może być bezpośrednio obserwowane [Suddaby, 2010]. Konstrukt ten zostal, jak dotąd, opisany w dwojaki sposób. Pierwsze podejście, opisane przez Earleya i Ang [2003], określa CQ jako wielopostaciową, współzależną strukturę składającą się z trzech komponentów: poznawczego (w tym metapoznawczego), motywacyjnego i behawioralnego. Inteligencja kulturowa jest wynikiem interakcji tych elementów, a jednostka musi je wszystkie 
posiadać, by zostać uznaną za inteligentną kulturowo. Earley i Ang nie precyzują jednak, w jaki sposób rozmaite komponenty CQ wchodzę ze sobą w interakcję. Wiadomo jedynie, że poszczególne aspekty CQ przenikają się i oddziałują na siebie nawzajem. Zgodnie z ich rozumieniem CQ komponent kognitywny inteligencji kulturowej jest najbardziej zbliżony do powszechnego rozumienia inteligencji; jest to wiedza na temat innych kultur, którą jednostka nabywa i zachowuje do zastosowania w przyszłości. Z kolei już to, jak jednostka przetwarza i użytkuje te informacje, stanowi część komponentu metakognitywnego.

Komponent motywacyjny to wewnętrzna motywacja jednostki do podjęcia wysiłku i kierowania energii i uwagi w celu skutecznego funkcjonowania w odmiennym kulturowo otoczeniu.

Element behawioralny CQ odzwierciedla zdolność jednostki do poprawnych werbalnych i niewerbalnych działań czy zachowań wtedy, gdy znajdzie się ona w sytuacji interakcji z osobami z różnych kultur. Zdaniem Earleya i Mosakowski [2004] nie wystarczy bowiem wykazać się wiedzą o kulturze gospodarzy, zagranicznych gości czy kolegów, trzeba jeszcze udowodnić swoim postępowaniem i postawą, że się ich rozumie i potrafi poruszać w ich świecie.

Tak więc, w skrócie, konceptualizacja CQ według Earlya i Ang sprowadza się do posiadania odpowiedniej wiedzy, przetwarzania jej oraz zarówno motywacji do jej zastosowania w praktyce, jak i odpowiednich umiejętności.

Przedstawione podejście znalazło wyraz $\mathrm{w}$ narzędziu opracowanym przez Soon Ang [Ang i in., 2007] do pomiaru poszczególnych elementów inteligencji kulturowej. Celem powstania instrumentu był pomiar indywidualnych różnic w zakresie CQ. Kwestionariusz o nazwie CQS (Cultural Intelligence Scale) składał się z dwudziestu twierdzeń w siedmiostopniowej skali Likerta (od 4 do 6 stwierdzeń dla każdego komponentu CQ). Nieco inne narzędzie, uwzględniające podział: głowa - serce - ciało, jako odpowiedniki poszczególnych komponentów CQ (w tym ujęciu są to: komponent poznawczy, emocjonalno-motywacyjny oraz fizyczny), przedstawili Earley i Mosakowski [2004]. W tym przypadku zastosowano trzy grupy twierdzeń w pięciostopniowej skali Likerta dla każdej kategorii. Obszarem wspólnym dla obu narzędzi była część poznawcza i w pewnym zakresie - motywacyjna. $Z$ tego względu w tabeli 1 zamieszczono twierdzenia z obu kwestionariuszy, użyteczne w kontekście prowadzenia badań międzynarodowych.

Drugie podejście, wprowadzone pierwotnie przez Thomasa i Inksona [2004] i później zmodyfikowane [Thomas i in., 2008], ujmuje inteligencję kulturową jako system współoddziałujących na siebie wiedzy i umiejętności, połączonych elementem metapoznawczym, pozwalającym jednostkom dostosowywać się, wybierać i kształtować kulturowe aspekty otoczenia. Zgodnie z tym podejściem CQ to wiedza i umiejętności rozwijane w specyficznym kontekście kulturowym (lub międzykulturowym), których efektywność, wyrażona w postaci kulturowo inteli- 
gentnego zachowania, zależy od elementu metapoznawczego [Thomas i in., 2008]. Kulturowe metapoznanie w tym ujęciu dotyczy procesów monitorowania i regulowania świadomych i celowych myśli, czyli zachowania podwyższonej świadomości i zwiększonej uwagi wobec bieżących doświadczeń kulturowych i odmienności otoczenia (w tym świadomości założeń, emocji, motywacji, intencji, zachowań i umiejętności, zarówno w odniesieniu do samego siebie, jak i osób reprezentujących odmienną kulturę) oraz kontrolowania działań poznawczych w celu skutecznego poradzenia sobie w sytuacji międzykulturowej.

Tabela 1. Wybrane elementy kwestionariusza do pomiaru inteligencji kulturowej (CQS) oraz kwestionariusza stworzonego przez Earleya i Mosakowski

\begin{tabular}{|c|c|}
\hline $\begin{array}{l}\text { Komponenty CQ ujęte } \\
\text { w kwestionariuszu }\end{array}$ & $\begin{array}{c}\text { Przykładowe twierdzenia kwestionariusza CQS użyteczne z punktu } \\
\text { widzenia prowadzenia badań międzynarodowych }\end{array}$ \\
\hline $\begin{array}{l}\text { 1. CQ strategia (kompo- } \\
\text { nent metapoznawczy) }\end{array}$ & $\begin{array}{l}\text { - jestem świadomy wiedzy kulturowej, którą stosuję, kiedy wchodzę } \\
\text { w interakcje z osobami o odmiennej kulturze } \\
\text { - modyfikuję moją wiedzę kulturową, kiedy wchodzę w interakcje } \\
\text { z osobami reprezentującymi nieznaną mi kulturę } \\
\text { - jeśli doświadczę czegoś nieoczekiwanego podczas pracy w nowym } \\
\text { otoczeniu kulturowym, wykorzystuję to doświadczenie, aby kreo- } \\
\text { wać nowe sposoby podejścia do innych kultur w przyszłości }\end{array}$ \\
\hline $\begin{array}{l}\text { 2. CQ wiedza (kompo- } \\
\text { nent poznawczy) }\end{array}$ & $\begin{array}{l}\text { - znam systemy prawne i ekonomiczne obowiązujące w innych kul- } \\
\text { turach } \\
\text { - znam wartości kulturowe oraz wierzenia religijne innych kultur } \\
\text { - znam zasady wyrażania niewerbalnych zachowań w innych } \\
\text { kulturach }\end{array}$ \\
\hline $\begin{array}{l}\text { 3. CQ motywacja (kom- } \\
\text { ponent motywacyjny) }\end{array}$ & $\begin{array}{l}\text { - stosunkowo łatwo potrafię zaadaptować się do stylu życia } \\
\text { panującego w odmiennej kulturze } \\
\text { - jestem pewien, że potrafię utrzymywać kontakty towarzyskie } \\
\text { z miejscowymi reprezentującymi nieznaną mi kulturę } \\
\text { - jestem pewien, że potrafię radzić sobie w nieznanej mi sytuacji } \\
\text { kulturowej }\end{array}$ \\
\hline $\begin{array}{l}\text { 4. CQ zachowanie (kom- } \\
\text { ponent behawioralny) }\end{array}$ & $\begin{array}{l}\text { - łatwo zmieniam modulację swojego głosu (jego ton, akcenty itp.), } \\
\text { aby dopasować się do osób o odmiennej kulturze } \\
\text { - używam pauzy i ciszy w różny sposób, aby dopasować się do } \\
\text { danego kontekstu kulturowego } \\
\text { - modyfikuję swoje zachowanie niewerbalne, jeśli wymaga tego } \\
\text { kontekst interakcji międzykulturowej }\end{array}$ \\
\hline
\end{tabular}

Źródło: Opracowanie własne na podstawie kwestionariusza opublikowanego przez Cultural Intelligence Center oraz [Earley, Mosakowski, 2004].

Oba podejścia traktują CQ jako konstrukt wielowymiarowy, a inteligencja kulturowa w ich ujęciu jest specyficzną formą inteligencji, dającą się wyraźnie odróżnić 
od inteligencji społecznej czy emocjonalnej [Earley, Ang, 2003]. Osoba inteligentna kulturowo ma wysoką motywację do tego, by w obliczu różnic w normach, wartościach i postępowaniu partnerów w zróżnicowanym kulturowo środowisku pokonywać pojawiające się bariery. Jest również gotowa do poświęcenia czasu i wysiłku na adaptację do nowej kultury oraz wierzy we własną sprawczość i skuteczność w tym zakresie. Jednocześnie posiada zaawansowaną wiedzę o zwyczajach kulturowych i strategiach komunikacyjnych swoich partnerów oraz własnych i zna wpływ kultury na zachowanie i sposób komunikacji. Poddaje refleksji własne zachowanie, świadomie je planuje i uczy się na błędach. W sytuacji spotkania międzykulturowego potrafi działać skutecznie, stosownie dopasowując werbalny i niewerbalny styl komunikacji do partnera rozmowy, kontekstu i całej sytuacji [Piwowarczyk, 2016].

\section{Rola inteligencji kulturowej w prowadzeniu międzynarodowych badań marketingowych}

Wydaje się, że rozważania na temat roli, jaką w międzynarodowych badaniach marketingowych może odgrywać inteligencja kulturowa, to interesująca, nowa perspektywa postrzegania tych badań. Zarówno elementy CQ wyróżnione w podejściu Earlya i Ang, jak i rozumienie Thomasa i in. może być użyteczne w wyjaśnieniu problemów metodologicznych na poszczególnych etapach prowadzenia badań. W kontekście badań rynków międzynarodowych wyróżnia się podobne etapy jak $\mathrm{w}$ przypadku badań rynku krajowego, czyli: definiowanie problemu, projektowanie badania, przeprowadzenie badania, analizę i interpretację danych oraz prezentowanie wyników. Jednakże, chociaż podstawowe zasady prowadzenia badań marketingowych są identyczne niezależnie od tego, czy badania są przeprowadzane w kontekście rynku krajowego, czy rynków międzynarodowych, chociaż stosuje się te same narzędzia i techniki badawcze, a sam cel badań pozostaje w zasadzie ten sam - dostarczanie aktualnej i wiarygodnej informacji, to jednak prawdopodobieństwo zetknięcia się z trudnościami na drodze badawczej jest $\mathrm{w}$ przypadku badaczy międzynarodowych o wiele większe. Badania międzynarodowe obejmują bowiem szerszy zakres tematyczny oraz charakteryzują się większą złożonością i odmiennością otoczenia i respondentów [Schroeder, Bartosik-Purgat, Mruk, 2013].

Problemy metodologiczne wynikające $\mathrm{z}$ prowadzenia badań $\mathrm{w}$ otoczeniu wielokulturowym pojawiają się na wszystkich etapach badania [Malhotra, Agarwal, Peterson, 1996; Karcz, 2004]. Kwestie problematyczne są więc bardzo liczne $\mathrm{i}$ ich opis wykraczałby znacznie poza zakres tego opracowania. $Z$ tego względu skupiono się głównie na tych aspektach, które szczególnie wiążą się z wykorzy- 
staniem inteligencji kulturowej. Zdecydowano się również na ujęcie CQ według Earlya i Ang, ze względu na większe rozpowszechnienie tego modelu, jego większą przejrzystość oraz wypracowane w oparciu o tę koncepcję narzędzie badawcze, pozwalające mierzyć poziom CQ osób zaangażowanych na różnych etapach badań (por. tab. 2).

Tabela 2. Problemy metodologiczne w badaniach międzynarodowych a znaczenie inteligencji kulturowej

\begin{tabular}{|c|c|}
\hline $\begin{array}{c}\text { Problemy metodologiczne na różnych etapach } \\
\text { procesu badań międzynarodowych }\end{array}$ & $\begin{array}{c}\text { Wykorzystanie danego komponentu } \\
\text { inteligencji kulturowej do rozwiązania } \\
\text { problemu badawczego }\end{array}$ \\
\hline $\begin{array}{l}\text { Definiowanie problemu } \\
\text { - porównywalność zjawisk/zachowań/funkcji } \\
\text { produktów } \\
\text { - wartości uniwersalne i specyficzne } \\
\text { - wyizolowanie kryterium samoodniesienia }\end{array}$ & $\begin{array}{l}\text { CQ wiedza (komponent poznawczy) } \\
\text { CQ strategia (komponent metapoznawczy) }\end{array}$ \\
\hline $\begin{array}{l}\text { Projektowanie badania } \\
\text { - rozstrzygnięcie dylematu emic-etic } \\
\text { - ekwiwalencja próby badawczej (potencjalna } \\
\text { odmienność ról w procesie podejmowania } \\
\text { decyzji rynkowych) }\end{array}$ & $\begin{array}{l}\text { CQ wiedza (komponent poznawczy) } \\
\text { CQ strategia (komponent metapoznawczy) }\end{array}$ \\
\hline $\begin{array}{l}\text { Przeprowadzenie badania } \\
\text { - dobór zespołu realizującego badania terenowe } \\
\text { - dobór i szkolenie ankieterów, kontrola pracy } \\
\text { w terenie } \\
\text { - inne kwestie, jak np. tzw. przeszkoda grzecznoś- } \\
\text { ciowa, znaczenie kontekstu w danej kulturze }\end{array}$ & $\begin{array}{l}\text { CQ strategia (komponent metapoznawczy) } \\
\text { CQ motywacja (komponent motywacyjny) } \\
\text { CQ zachowanie (komponent behawioralny) }\end{array}$ \\
\hline $\begin{array}{l}\text { Analiza i interpretacja danych } \\
\text { - ekwiwalencja metryczna i ekwiwalencja ana- } \\
\text { lizy danych (skłonność do udzielania od- } \\
\text { powiedzi wyłącznie neutralnych bądź skraj- } \\
\text { nych) }\end{array}$ & CQ wiedza (komponent poznawczy) \\
\hline $\begin{array}{l}\text { Prezentowanie wyników } \\
\text { - sposób komunikowania wyników badań: } \\
\text { - tradycyjny (dane liczbowe, wykresy slajdy) } \\
\text { czy niekonwencjonalny (storytelling, komiks, } \\
\text { infografika, quiz) } \\
\text { - ustny lub pisemny }\end{array}$ & $\begin{array}{l}\text { CQ strategia (komponent metapoznawczy) } \\
\text { CQ motywacja (komponent motywacyjny) } \\
\text { CQ zachowanie (komponent behawioralny) }\end{array}$ \\
\hline
\end{tabular}

Źródło: Opracowanie własne na podstawie: [Malhotra, Agarwal, Peterson, 1996; Earley, Ang, 2003; Karcz, 2004; Mazurek-Łopacińska, Sobocińska, 2014].

Wydaje się, że znaczenie wykorzystania poszczególnych komponentów CQ na różnych etapach procesu badań międzynarodowych będzie się różnić m.in. w zależności od występowania lub braku występowania bezpośredniego kontaktu badacz - badany lub badacz - badacz lokalny. Przykładowo, aby przeprowadzić badanie bezpośrednie np. w postaci indywidualnych zakupów w towarzystwie 
moderatora, osoba ta będzie potrzebowała znacznie większych zasobów w zakresie CQ motywacja i CQ zachowanie niż ankieter rozdający kwestionariusze w centrum handlowym. Wysoki poziom inteligencji kulturowej badaczy jest również ważny w sytuacji, gdy w zespole znajdują się osoby z lokalnych ośrodków badawczych, znające specyfikę kulturową danego rynku [Mazurek-Łopacińska, Sobocińska, 2014]. Rola lokalnych badaczy jest szczególnie istotna na wczesnych etapach projektowania badania i potem w trakcie analizy i interpretacji wyników, wnoszą oni bowiem swój wkład w formułowanie pytań badawczych i tworzenie instrumentów do badań, dobór próby i metodologię zbierania danych. To właśnie te osoby są szczególnie predysponowane do interpretacji wyników badań w kontekście lokalnych uwarunkowań, jak również do wyjaśnienia wszelkich anomalii i różnic [Douglas, Craig, 2001]. Jednak aby lokalni badacze mogli stać się kimś więcej niż jedynie wykonawcami centralnie zaprojektowanego badania, konieczna jest efektywna współpraca pomiędzy nimi a pozostałymi członkami zespołu. Współpraca ta uwarunkowana jest m.in. wzajemnym zrozumieniem, otwartością na odmienną perspektywę badaczy i dobrą komunikacją. Poziom inteligencji kulturowej badaczy może być jedną z przesłanek decydujących o składzie zespołu badawczego w przestrzeni międzykulturowej.

„Ludzie o wysokim CQ, znalazłszy się w całkowicie nieznanym otoczeniu społecznym, są w stanie nauczyć się, które sygnały są ważne, by zrozumieć, co tak naprawdę dzieje się wewnątrz danej kultury. [...] Wymaga to świeżego spojrzenia na nowe otoczenie kulturowe, bez narzucania wielu już istniejących idei, które określają, co dane rzeczy muszą oznaczać, czy w jaki sposób należy działać, by czynić postępy" [Early, Ang, 2003, s. 12]. Taki zestaw cech bezpośrednio łączy się z pojęciami istotnymi dla prowadzenia międzynarodowych badań marketingowych, jak kryterium samoodniesienia, ekwiwalencja czy omówione dalej podejście emic.

Kryterium samoodniesienia to nieświadome odwołanie się do własnych wartości, norm kulturowych, stylu życia, wiedzy i doświadczenia w rozumieniu zjawisk [Kumar, 2015]. W przypadku gdy badacz zostaje skonfrontowany z odmiennym i nieznanym otoczeniem kulturowym, może instynktownie zastosować własne rozumienie sytuacji, oparte na wspomnianych wyżej elementach. Kryterium samoodniesienia nie tylko zakłóca zdolność do definiowania problemu w jego prawdziwym świetle, ale również uniemożliwia badaczowi zrozumienie różnic kulturowych i w dalszej kolejności uznania wagi tych różnic. Praktyka przedsiębiorstw funkcjonujących w otoczeniu międzynarodowym pokazuje wiele takich przykładów, jak chociażby uznawanie przez zachodnie koncerny za pewnik tego, że rola farmaceuty sprowadza się do wydania przepisanego leku, ból należy jak najszybciej stłumić odpowiednią tabletką [Flores, Karsh, 2012], a jednorazowa pieluszka powinna jak najdłużej zapewniać niemowlęciu ochronę przed przemoczeniem (przypadek Procter \& Gamble w Japonii opisany w Cavusgil i in. [2009]). Tymczasem rzeczywistość okazuje się zupełnie inna; miejscowi farmaceuci, np. 
w Indiach, często stawiają diagnozy i wypisują odpowiednie leki, a zachodnia medycyna w wielu krajach jest postrzegana jako zakłócająca wewnętrzną równowagę organizmu. Prowadząc badania marketingowe na rynkach azjatyckich, ważne jest, żeby oprzeć się pokusie klasyfikacji potencjalnych pacjentów na zwolenników i przeciwników leków aptecznych, ale raczej zrozumieć ich dążenie do łączenia medycyny tradycyjnej i zachodniej.

Z kolei zachowując ekwiwalencję (równoważność) badań, badacz zapewnia porównywalność wyników badań przeprowadzonych w różnych krajach. Przykładowo ekwiwalencja pojęciowa dotyczy rozstrzygnięcia, czy dane pojęcie lub obiekt oznacza to samo i czy wyrażone jest poprzez te same postawy i zachowania we wszystkich badanych kulturach. Nawet tak fundamentalne i bazowe pojęcia, jak piękno, młodość i zdrowie, choć wydają się uniwersalne, w rzeczywistości związane są z uwarunkowanymi kulturowo interakcjami pomiędzy członkami danych społeczności. Przekonała się o tym nasza rodzima marka CCC, próbując wypromować w reklamie w Turcji wizerunek Piotra Adamczyka, który jednakże nie odpowiadał standardom atrakcyjności mężczyzny w tym kraju.

Inny rodzaj ekwiwalencji to ekwiwalencja funkcjonalna, związana z tym, czy dane pojęcie, zachowanie lub produkt pełnią te same funkcje $\mathrm{w}$ różnych kulturach. Można to zilustrować przykładem nieudanej próby wprowadzenia na początku lat dziewięćdziesiątych na polski rynek świetnie sprzedającego się w krajach bardziej rozwiniętych gospodarczo szamponu i odżywki w jednym firmy Procter \& Gamble, o nazwie „Wash and Go". W kraju, w którym rzadko kto w tamtym czasie w ogóle używał tradycyjnych odżywek do włosów, trudno było przekonać ewentualnych odbiorców do zalet produktu typu "2 w 1". Tłumaczenie konsumentom, że mogą już przestać używać tradycyjnych odżywek, które trzeba nakładać na włosy po uprzednim umyciu ich szamponem, było w ówczesnym czasie całkowitym nieporozumieniem i przykładem zignorowania pewnych realiów cywilizacyjnych i kulturowych, nic więc dziwnego, że polski odbiorca zareagował niechęcią. Powstała nawet złośliwa plotka, że „po takim czymś z głowy wychodzą włosy" [Doliński, 1998]. Firma P\&G weszła z produktem na rynek polski zbyt wcześnie, ignorując funkcję, jaką spełniały produkty do pielęgnacji włosów w Polsce w tym czasie. Postawa firmy, która "wie lepiej”, przyczyniła się do jednej z największych porażek produktowych lat dziewięćdziesiątych.

W tym kontekście podejście opisane przez Earley i Ang zwraca również uwagę na coś, co zostało wcześniej określone przez mistrza zen Shunryu Suzukiego jako "umysł początkującego" (beginner's mind). Suzuki pisał tak: „W umyśle początkującego jest wiele możliwości, w umyśle eksperta - parę" [Suzuki, 2010, s. 32]1.

1 Tłumaczenie polskie nie oddaje w pełni istoty słów Suzukiego: „In the beginner's mind there are many possibilities, but in the expert's mind there are few". Roshi wyraźnie pisze, iż owych możliwości w umyśle eksperta jest po prostu mało. 
Zgodnie z tą ideą, gdy jednostka traktuje siebie jako specjalistę, który już wszystko wie, wtedy zamyka się na nową wiedzę, traci ciekawość i rezygnuje z odkrywania świata. „Świeże spojrzenie” Earleya i Ang, jak również „umysł początkującego" to podejścia, dla których charakterystyczne są otwartość, brak uprzedzeń oraz pozbycie się ograniczających "filtrów”. Jest to postawa szczególnie pożądana z punktu widzenia badacza marketingowego działającego $\mathrm{w}$ otoczeniu międzynarodowym i międzykulturowym, dla którego brak z góry przyjętych założeń stwarza szansę na uzyskanie cennych insightów ${ }^{2}$, czyli pozwala na zrozumienie niejawnych potrzeb konsumenta.

Prowadzenie badań $\mathrm{w}$ otoczeniu wielokulturowym jest również związane $\mathrm{z}$ wyborem podejścia emic lub etic. Pierwsze z nich polega na badaniu zjawiska "z wnętrza" systemu, kiedy badaniom poddaje się tylko jedną kulturę, a zastosowane kryteria i zasady odnosi się do wewnętrznych charakterystyk tej kultury [Karcz, 2004]. W poznawaniu zachowań konsumentów na rynkach zagranicznych zgodnie z podejściem emic znajdują zastosowanie metody, w których przyjmuje się sposób postrzegania badanego. $Z$ kolei w podejściu etic bada się zjawiska "z zewnątrz", badaniom poddaje się wiele kultur, a przyjęte kryteria mają charakter uniwersaliów kulturowych. Podejście to wymaga uogólniania podobieństw kulturowych i stosowania zestandaryzowanych narzędzi $\mathrm{w}$ badaniu zjawisk w różnych kulturach. Według Adama Sagana [2003] w nurcie emic dominują badania jakościowe, a szczególnie tzw. emikalne narzędzia gromadzenia danych, takie jak np. otwarte, kontekstowe pytania strukturalne czy technika wolnych list i skojarzeń słownych. Natomiast w nurcie etic mieszczą się przede wszystkim badania ilościowe, głównie kwestionariusze standaryzowane i techniki skalowania (skale Likerta, Guttmana, dyferencjał semantyczny). Z samej nazwy „badania międzykulturowe", zdaniem Malhotry i in. [1996], wynika konieczność łączenia obu podejść, gdzie określenie „kulturowe” wymusza podejście emic, a „między” perspektywę etic.

\section{Podsumowanie i kierunki dalszych badań}

W artykule przedstawiono koncepcję CQ jako współzależną strukturę kilku wzajemnie na siebie oddziałujących komponentów oraz możliwości jej zastosowania $\mathrm{w}$ zakresie różnych aspektów procesu badawczego w kontekście międzynarodowym. Występowanie bezpośredniego kontaktu zarówno z respondentami, jak i w ramach zespołu badawczego może mieć istotny wpływ na wykorzystanie poszczególnych komponentów CQ w rozwiązywaniu problemów metodologicznych, które z reguły nie występują w przypadku badań w jednorodnej kulturowo

2 Polskie tłumaczenie „wgląd” nie przyjęło się w literaturze marketingowej. 
populacji. Ponadto emikalny charakter badań niejako wymusza zanurzenie się w rzeczywistości badanych, kiedy to wysoki poziom CQ, szczególnie w obszarze metakognitywnym i behawioralnym, jest szczególnie pożądany.

W kontekście niniejszych rozważań i dalszej eksploracji roli inteligencji kulturowej w międzynarodowych badaniach marketingowych interesujące wydaje się rozwinięcie wątku metodologicznego. Z pewnością inteligencja kulturowa będzie miała do odegrania większą rolę np. w badaniach etnograficznych niż sondażowych, co może zostać wykorzystane do kształcenia przyszłych badaczy rynków międzynarodowych. Ponadto warto kontynuować i pogłębiać badania nad pomiarem CQ i tworzeniem profili inteligencji kulturowej, umożliwiających taki dobór osób do zespołu prowadzącego badania międzynarodowe, który będzie optymalny pod względem posiadanych zdolności poznawczych, behawioralnych oraz motywacyjnych.

\section{Bibliografia}

Alon I., Higgins J.M., 2005, Global leadership success through emotional and cultural intelligence, Business Horizons, vol. 48, no. 6.

Ang S., Van Dyne L., Koh C., Ng K.Y., Templer K.J., Tay C., Chandrasekar N.A., 2007, Cultural Intelligence. Its Measurement and Effects on Cultural Judgment and Decision Making, Cultural Adaptation and Task Performance, Management and Organization Review, vol. 3 , issue 3 .

Cavusgil S.T., Knight G., Riesenberger J., Yaprak A., 2009, Conducting Market Research for International Business, Businessexpert Press.

Doliński D., 1998, Specyfika kulturowa, Aida Media, nr 3.

Earley P.C., Ang S., 2003, Cultural intelligence. Individual interactions across cultures, Stanford University Press, Palo Alto, CA.

Earley P.C., Mosakowski E., 2004, Cultural Intelligence, Harvard Business Review, October.

Eisenberg J., Lee H.-J., Brück F., Brenner B., Claes M.-T., Mironski J., Bell R., 2013, Can business schools make students culturally competent? Effects of cross-cultural management courses on cultural intelligence, Academy of Management Learning \& Education, vol. 12, no. 4.

Flores P., Karsh J., 2012, Getting to know you. Conducting ethnographic research with Hispanic consumers, Quirk's Marketing Research Review, February.

Groves K.S., Feyerherm A., Gu M., 2015, Examining Cultural Intelligence and Cross-Cultural Negotiation Effectiveness, Journal of Management Education, vol. 39, issue 2.

Karcz K., 2004, Międzynarodowe badania marketingowe. Uwarunkowania kulturowe, Polskie Wydawnictwo Ekonomiczne, Warszawa.

Kumar V., 2015, Global Marketing Research, Sage, New Delhi.

Malhotra N.K., Agarwal J., Peterson M., 1996, Methodological issues in cross-cultural marketing research. A state-of-the-art review, International Marketing Review, vol. 13.

Mazurek-Łopacińska K., Sobocińska M., 2014, Triangulacja w badaniach marketingowych zachowań konsumentów na rynkach międzynarodowych, Handel Wewnętrzny, nr 1.

Ott D.L., Michailova S., 2018, Cultural intelligence. A review and new research avenues, International Journal of Management Reviews, vol. 20, issue 1. 
Pincus J., 2014, How to address cultural conceptions of illness, health and wellness, Quirk's Marketing Research Review, November.

Piwowarczyk A.J., 2016, Istota i znaczenie inteligencji kulturowej w kontekście kształcenia uniwersyteckiego, E-Mentor, nr 1.

Sagan A., 2003, Ekwiwalencja pomiaru w badaniach międzykulturowych, [w:] Euromarketing. Przedsiębiorstwo i konsument w perspektywie integracji europejskiej, red. J.W. Wiktor, Akademia Ekonomiczna w Krakowie, Kraków.

Schroeder J., Bartosik-Purgat M., Mruk H., 2013, Międzynarodowe badania marketingowe, Wydawnictwo Uniwersytetu Ekonomicznego w Poznaniu, Poznań.

Simpson D., 2015, Znaczenie inteligencji kulturowej w kierowaniu zespołami międzynarodowymi, International Business and Global Economy, no. 34.

Suddaby R., 2010, Editor's comments. Construct clarity in theories of management and organization, Academy of Management Review, vol. 35, no. 3.

Suzuki S., 2010, Umyst zen, umyst początkującego, przeł. J. Dobrowolski, A. Sobota, Wydawnictwo Elay, Jaworze.

Thomas D.C., Inkson K., 2004, Cultural Intelligence. People Skills for Global Business, Barrett-Koehler Publishers.

Thomas D.C., Stahl G., Ravlin E.C., Poelmans S., Pekerti A., Maznevski M., Lazarova M.B., Elron E., Ekelund B.Z., Cerdin J.-L., Brislin R., Aycan Z., Au K., 2008, Cultural Intelligence. Domain and Assessment, International Journal of Cross Cultural Management, vol. 8.

D. Babińska (『) danuta.babinska@ue.katowice.pl

Katedra Zarządzania Międzynarodowego, Uniwersytet Ekonomiczny w Katowicach, ul. 1 Maja 47, 40-287 Katowice, Polska 